\title{
SPORULATION OF METARHIZIUM ANISOPLIAE VAR. ACRIDUM AND BEAUVERIA BASSIANA ON RHAMMATOCERUS SCHISTOCERCOIDES UNDER HUMID AND DRY CONDITIONS
}

\author{
Bonifácio Peixoto Magalhães ${ }^{1 *}$; Mark Stanislaw Goettel²; Heloisa da Silva Frazão ${ }^{1}$ \\ ${ }^{1}$ Embrapa Recursos Genéticos e Biotecnologia, Brasília, DF, Brasil. ${ }^{2}$ Agriculture \& Agri-Food \\ Canada, Lethbridge, AB, Canada
}

Submitted: June 11, 1999; Returned to authors for corrections: April 25, 2000; Approved: September 20, 2000

\section{SHORT COMMUNICATION}

\begin{abstract}
The sporulation of the fungi Metarhizium anisopliae var. acridum and Beauveria bassiana in cadavers of the grasshopper Rhammatocerus schistocercoides was studied in dry and humid environments. Both fungi were equally virulent against $R$. schistocercoides. However, internally, M. anisopliae produced more conidia than B. bassiana at 53\% and $75 \%$ relative humidity. Externally, there was no sporulation at $53 \%$ and $75 \%$ $\mathrm{RH}$, and M. anisopliae produced more conidia than B. bassiana at $100 \% \mathrm{RH}$.
\end{abstract}

Key words: entomopathogenic fungi, internal sporulation, grasshoppers, microbial control

Rhammatocerus schistocercoides is a serious pest of several crops and native pastures in Mato Grosso State, Brazil (8). The reduction or replacement of chemical insecticides by mycoinsecticides to control this insect is under investigation $(5,6)$. Metarhizium anisopliae var. acridum (= M. flavoviride; $1)$ is very infective to $R$. schistocercoides $(6,10)$, and Beauveria bassiana to Melanoplus sanguinipes (3). During previous research at Embrapa Genetic Resources and Biotechnology it was noted that $M$. anisopliae var. acridum sporulated profusely within dried cadavers of $R$. schistocercoides (10). We report here on a laboratory experiment devised to compare internal and external sporulation of $M$. anisopliae var. acridum and $B$. bassiana on $R$. schistocercoides cadavers kept in humid and dry conditions.

Insects. Insects used in this study were collected in the field (Silvânia, GO, Brazil) and maintained in $60 \mathrm{~cm} \times 60 \mathrm{~cm}$ x $80 \mathrm{~cm}$ cages in the laboratory at $25^{\circ} \mathrm{C}$ and $12 \mathrm{~h}$ photophase. They were fed sugar cane leaves, oats and wheat germ during 15 days before testing, without regard to gender.

Fungal isolates and culture. Isolates CG 423 (M. anisopliae var. acridum) and CG 425 (B. bassiana) were provided by Embrapa Genetic Resources and Biotechnology, Collection of Entomopathogenic Fungi, Brasília, DF. The isolate CG 423 was first found infecting the pallid grasshopper Schistocerca pallens in Rio Grande do Norte State (7), and the isolate CG 425 infecting $R$. schistocercoides in Mato Grosso (5). The fungi were cultured in SDAY (1\% neopeptone, $2 \%$ dextrose, $1.5 \%$ agar, and $1 \%$ yeast extract, completed to $1000 \mathrm{ml}$ distilled water, ph calibrated to 6.2) after retrieval from storage in liquid nitrogen. For the bioassay, the fungi were culture in rice as described by Magalhães and Frazão (4).

Bioassay. Groups of $30 R$. schistocercoides adults were tested with either M. anisopliae var. acridum (CG 423) or B. bassiana (CG 425). To perform the bioassays, insects were individually inoculated with $3 \mu \mathrm{l}$ of a conidial suspension (5000 conidia/insect) applied on the right pleural region with a micropipette. Insects were maintained in $17 \mathrm{~cm} \mathrm{x} 21 \mathrm{~cm} \mathrm{x}$ $25 \mathrm{~cm}$ cages (10/cage) at $25^{\circ} \mathrm{C}$ and 12 photophase and were fed sugar cane leaves, oats and wheat germ. Dead adults were removed daily. One femur was dissected from each insect and a drop of hemolymph was extracted and observed under the microscope for presence of blastospores.

\footnotetext{
* Corresponding author. Mailing address: Embrapa Recursos Genéticos e Biotecnologia, Caixa Postal 2372, CEP 70849-970, Brasília, DF, Brasil. Fax: (+5561) 3484-673,E-mail: boni@ cenargen.embrapa.br
} 
Sporulation test. Desiccators containing saturated solutions of $\mathrm{Mg}\left(\mathrm{NO}_{3}\right) \cdot 6 \mathrm{H}_{2} \mathrm{O}$ and $\mathrm{NaCl}$ to provide $53 \%$ and $75 \%$ relative humidity, respectively, were used for both fungi. Infected hoppers were then placed in $7 \mathrm{~cm}$ diameter Petri dishes left opened in the desiccators. The high humidity $(100 \%)$ was obtained by placing a small Petri dish $(3 \mathrm{~cm})$ containing moistened cotton inside $90 \mathrm{~cm}$ diameter dishes and sealing them with plastic film. In all cases, $M$. anisopliae var. acridum was incubated at $30^{\circ} \mathrm{C}$ and $B$. bassiana at $25^{\circ} \mathrm{C}$. This difference in temperature was due the better development of the $B$. bassiana isolate at $25^{\circ} \mathrm{C}$ (unpublished data). After 10 days, all hoppers were weighted to express conidial production by gram of insect. To estimate internal sporulation, cadavers were macerated with the aid of a $50 \mathrm{ml}$ commercial blender (Waring, Dynamics Corporation of America, Connecticut, USA) working at high speed for 20 seconds. To estimate external sporulation, cadavers were washed in a $10 \mathrm{ml}$ Tween 80 solution $(1 \%$ in distilled water; v/v) . Internal production of conidia by $M$. anisopliae var. acridum and B. bassiana was estimated by the colony forming units (CFU) method. The culture medium for M. anisopliae var. acridum was Oatmeal Dodine Agar $(5.55 \mathrm{~g}$ oat, $0.55 \mathrm{~g}$ magnesium sulfate, 0.83 potassium phosphate, $0.55 \mathrm{~g}$ sodium nitrate, $32.95 \mathrm{~g}$ agar, $5 \mathrm{ml}$ violet crystal, $4 \mathrm{~g}$ penicilin $\mathrm{G}, 10 \mathrm{~g}$ streptomycin, completed to $1000 \mathrm{ml}$ with distilled water). The same medium, except dodine, was used for $B$. bassiana. Dodine is a fungicide used to prepare selective media to grow specific fungi (1).

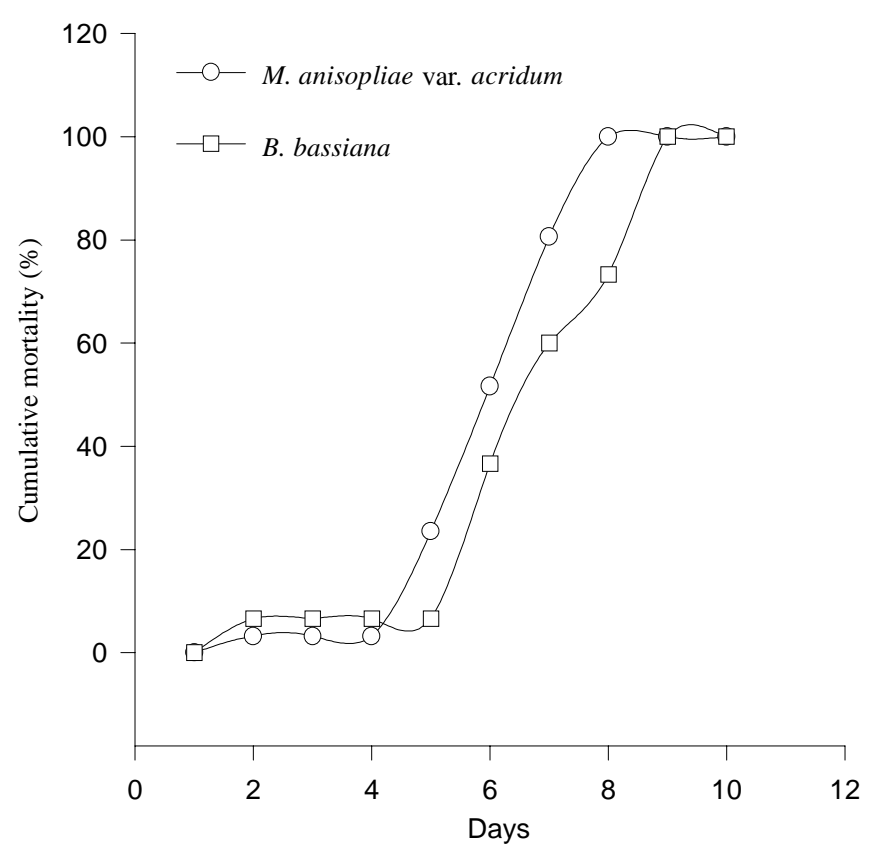

Figure 1. Mortality of Rhammatocerus schistocercoides adults infected with Metarhizium anisopliae var. acridum and Beauveria bassiana.
Both fungi were equally virulent against $R$. schistocercoides (Fig. 1), but $M$. anisopliae produced more conidia internally than $B$. bassiana at low humidity ( $<<0.03$; Fig. 2A). Externally, there was no sporulation when infected insects were incubated at $75 \% \mathrm{RH}$ and $M$. anisopliae var. acridum produced significantly more conidia than B. bassiana at $100 \%$ RH (P < 0.01 ; Fig. 2B). Regarding total fungal production per insect at $100 \% \mathrm{RH}$, M. anisopliae var. acridum produced more conidia and CFU $\left(7.1 \times 10^{8}\right)$ than B. bassiana $\left(4.1 \times 10^{8}\right)$.

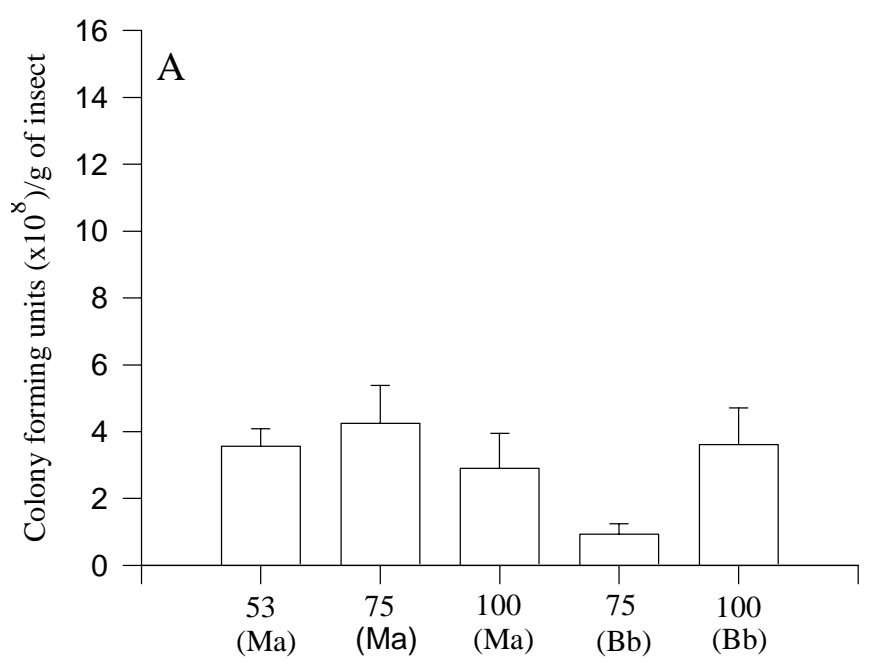

Relative humidity (\%)

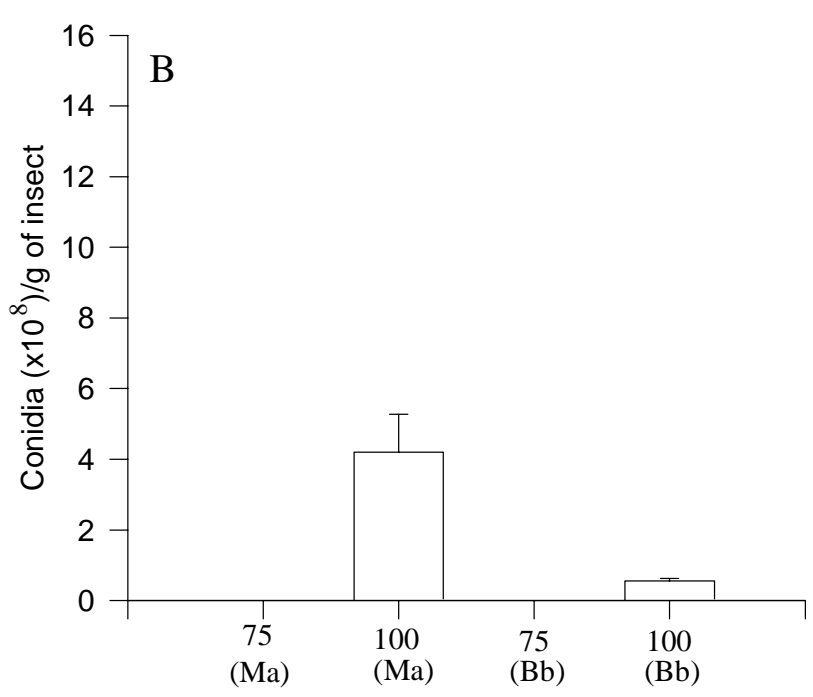

Relative humidity (\%)

Figure 2. (A) Colony forming units produced by Metarhizium anisopliae var. acridum (Ma) and Beauveria bassiana $(\mathrm{Bb})$ in the internal body cavity of Rhammatocerus schistocercoides at different humidities. (B) Conidial production by $M$. anisopliae var. acridum (Ma) and B. bassiana $(\mathrm{Bb})$ on the external body of $R$. schistocercoides at different humidities. 
Internal sporulation of $M$. anisopliae var. acridum in cadavers of the grasshopper Zonocerus variegatus was registered by Prior and Greathead (9). Since M. anisopliae var. acridum is being developed as mycoinsecticide against grasshoppers in Brazil, its ability to sporulate within cadavers under dry conditions would be important in the epizootiology of the disease, especially if applied in low humidity environments.

\section{ACKNOWLEDGMENTS}

We thank Marcos Faria, Embrapa Recursos Genéticos e Biotecnologia, for reviewing the manuscript. This work was supported in part by the Conselho Nacional de Desenvolvimento Científico e Tecnológico (CNPq).

\section{RESUMO}

\section{Esporulação de Metarhizium anisopliae var. acridum e Beauveria bassiana em Rhammatocecus schistocercoides em ambientes secos e úmidos}

A esporulação dos fungos Metarhizium anisopliae var. acridum e Beauveria bassiana em cadáveres do gafanhoto Rhammatocerus schistocercoides foi estudada em ambientes seco e úmido. As duas espécies de patógenos foram igualmente patogênicas a $R$. schistocercoides. Entretanto, internamente, M. anisopliae produziu mais conídios que B. bassiana a $53 \%$ e $75 \%$ de umidade relativa. Externamente, não houve esporulação a $53 \%$ e $75 \%$ de umidade relativa e M. anisopliae produziu mais conídios que $B$. bassiana a $100 \%$.

Palavras-chave: Fungos entomopatogênicos, esporulação interna, gafanhotos, controle microbiano.

\section{REFERENCES}

1. Chase, A.R.; Orborne, L.S.; Ferguson, V.M. Selective isolation of the entomopathogenic fungi Beauveria bassiana and Metarhizium anisopliae from an artificial potting medium. Florida Entomologist, 69: 285-292. 1996.

2. Driver, F.; Milner, R.; Trueman, J. A taxonomic revision of Metarhizium based on sequence analysis of ribosomal DNA. Mycological Res. 104: 134150. 1999.

3. Inglis, G.D.; Johnson, D.L.; Goettel, M.S. Field and laboratory evaluation of two conidial bacthes of Beauveria bassiana (Balsomo) Vuillemin against grasshoppers. The Canadian Entomologist, 129: 171-186. 1997.

4. Magalhães, B.P.; Frazão, H.S. Effects of temperature, water content and substrate on conidial production of Metarhizium flavoviride. Rev. Microbiol., 27: 242-246. 1996.

5. Magalhães, B.P. Microbial control of grasshopers in Brazil with the use of entomopathogenic fungi. pp. 429-433. In: Trends in Microbial Ecology (Martins, M.T. et al., eds.). 621 p. 1997.

6. Magalhães, B.P.; Faria, M.R.; Tigano, M.S; Sobral, B.W.S. Characterization and virulence of a Brazilian isolate of Metarhizium flavoviride Gams \& Rozsypal (Hyphomycetes). In: Microbial Control of Grasshoppers and Locusts (Jonhson D.L. \& Goettel, M.S., eds.). Memoirs of the Entomological Society of Canada, 171: 313-321. 1997.

7. Moreira, M.A.; Magalhães, B.P.; Valadares, M.C.C.; Chagas, M.C.M. Occurrence of Metarhizium flavoviride Gams \& Rozsypal (Hyphomycetes) on Schistocerca pallens (Thunberg) (Orthoptera: Acrididae) in Rio Grande do Norte, Brazil. Anais da Sociedade Entomológica do Brasil, 25: 359-361. 1996.

8. Miranda, E.E.; Lecoq, M.; Pierrozzi JR., I.; Duranton, F. F.; Batistella, M. O gafanhoto do Mato Grosso: balanço e perspectivas de 4 anos de pesquisas. 1992-1996. Campinas / Montpellier: EMBRAPA-NMA / CIRAD-GERDATPRIFAS, 1996. 146p.

9. Prior, C.; Greathead, D.J. Biological control of locusts: the potential for the exploitation of pathogens. FAO Plant Protec. Bull., 37: 37-38. 1989.

10. Vicentini, S.; Magalhães, B.P. Infection of the grasshopper Rhammatocerus schistocercoides Rehn by the entomopatogenic fungus Metarhizium flavoviride Gams \& Rozsypal. Anais da Sociedade Entomológica do Brasil, 25: 309-314. 1996 